present road construction programme in Germany is on so large a scale, and has been pushed forward so rapidly that great improvements in technical matters have ensued in connexion with road and bridge construction. At the Congress these will be discussed by Government, scientific and industrial experts. The road building machinery exhibition will be held in the open on the Munich Fair Ground, and will show the visitors the very rapid progress made in the mechanization of road construction. The quality of the materials used and the design of the machines have been vastly improved. The Congress will not be confined to purely business sessions. The German motor roads are not built merely for transport purposes. An attempt has been made to build them in such a way that they are in harmony with the landscape and the country in which they lie. Included therefore in the Congress programme are excursions and journeys of inspection over specially constructed motor roads and over the German Alpine highways. At the same time as the Congress there will be an art exhibition on roads as seen by modern art. This is an attempt to demonstrate the strong impression modern art has received from the inspiration of the new roads. It is anticipated that the first 600 miles of the new motor roads (autobahn) will be thrown open to traffic in the coming autumn. In two years time, thoroughfares will be completed between Hamburg and Karlsruhe, Stettin and Munich, Ruhr and Karlsruhe, and Stuttgart to Salzburg via Munich.

\section{Crops and Livestock in England and Wales}

THE Ministry of Agriculture and Fisheries has recently issued the first part of its publication, "Agricultural Statisties, 1934", entitled "Acreage and Production of Crops and Number of Livestock in England and Wales" (London: H.M. Stationery Office, $1 s$. $6 d$. net), a report which summarizes the annual returns from all holdings exceeding one acre. An outstanding feature is the arrest of the continuous change from arable to grass that has been going on since the Great War, the area under permanent grass showing a reduction on the previous year, whereas the total area under corn has expanded during the same period. As regards roots, the acreage under sugar beet reached a new record figure; that under fodder roots and potatoes, on the other hand, showed a decline. Yields were generally high, being above the average for all corn crops, potatoes, mangolds, hops and several kinds of fruit, though appreciably below normal for hay, turnips and swedes. The numbers of cattle, dairy cows, pigs and poultry have risen since 1933, whereas those for sheep and horses have declined, and as might be expected the output of meat and livestock products, eggs and milk have all shown considerable increases, while the wool clip was substantially reduced. An interesting feature of the report lies in the attainment of many record figures, the yield of wheat and apples being attributable no doubt to the favourable season, and the output of dairy and poultry products to the increase in numbers of cows and birds maintained. Records in area, total production and yield per acre were also reached in the case of sugar beet, while the area under oats, turnips and swedes fell to the lowest figure yet attained, reflecting the changes that are taking place in farming practice.

\section{Mining and Fuel Research at Sheffield}

WE have received from the University of Sheffield a report on the research work done in the Depart. ments of Mining and Fuel Technology during the year 1934-35. The former includes numerous subjects, such as mine ventilation, mine lighting, research on trailing cables, accuracy of mine surveys (in which we miss, however, any reference to the very valuable work done by the Institution of Mine Surveyors), subsidence resulting from mining operations, gas testing, movement of firedamp, fireproofing of mine timber, whilst in the Department of Fuel Technology the composition and decomposition and analysis of coal have been carefully studied. The formation of coke, the combustion of coke and the testing of coke have also received attention. A perusal of this pamphlet cannot fail to be of interest to colliery managers.

\section{Symbols for Heat and Thermodynamics}

AN attempt will be made to relieve the present chaotic situation with regard to symbols for equations in thermodynamics at an international conference which has been called by the American Society of Mechanical Engineers, to be held in New York on September 14-15, 1936. The Conference has been arranged for this time so that some of the delegates to the World Power Conference to be held the week previous in Washington, D.C., may also act as representatives at the Symbols Conference. American usage in regard to such symbols has become fairly well standardized; but other lists have been issued by various European bodies. The Conference will endeavour to compromise the differences in the several lists.

\section{Fifty Years of West Ham}

THE jubilee of the incorporation of the borough of West Ham has been the occasion for the publication of a volume illustrated by maps, photographs and old prints on the history and past and present activities of the borough ("Fifty Years a Borough". Edited by D. McDougall. West Ham County Borough Council 1936). The chief scientific interest in this municipal enterprise is the full account of the growth of the borough from Anglo-Saxon times and its relationship to the Lea and other rivers which were important influences in deciding direction of growth. The chapters on the local government and social services are also of considerable interest.

\section{Sterilization Operations in the United States}

According to a Science Service bulletin, steady increase in sterilization operations performed on insane and feeble-minded patients in the United States is reported by the Human Betterment Foundation, Pasadena. A total of 23,092 such operations 
had been officially performed up to January 1, 1936. This does not include operations of this nature privately performed, but is limited to those performed under State laws in the institutions of the twentyeight States now having sterilization laws in force.

\section{Announcements}

Prof. J. Basil Buxton, professor of animal pathology in the University of Cambridge, and director of the Institute of Animal Pathology and of the University Field Laboratories, Cambridge, has been appointed acting principal and acting dean of the Royal Veterinary College from September 25, and to succeed Sir Frederick Hobday as principal and dean on the retirement of Sir Frederick after the opening of the main block of the new college buildings.

AT a recent meeting of the North East Coast Institution of Engineers and Shipbuilders the following awards were made: Institution Gold Medals (Engineering), to Eng. Comdr. C. J. Hawkes and G. F. Hardy, for a paper entitled "Friction of Piston Rings"; (Shipbuilding), to R. C. Thompson, for a paper entitled "Modernizing the Motor Vessels 'Silverpine' and 'Silverlarch' and Increasing 'Their Service Speed"; M. C. James Medal, to W. C. S. Wigley, for a paper entitled, "The Theory of the Bulbous Bow and Its Practical Application"; Institution Scholarship, to Anthony Gilehrist ; Thomas Fenwick Reed Medal, to Dr. Will Pratt.

THE second International Congress of the Inter. national Association for Testing Materials will be held in London on April 19-24, 1937, under the presidency of Sir William Bragg. The Congress will be open to anyone on payment of membership fee. The subjects selected for discussion will be classed into the following groups: A, Metals; B, Inorganic Materials ; C, Organic Materials ; D, Subjects of General Importance. Further information can be obtained from the honorary secretary, Mr. K. Headlam-Morley, 28 Victoria Street, London, S.W.1.

Dr. Max Bodenstein, professor of physical chemistry at Berlin, has been awarded the Bunsen Medal by the German Bunsen Society for applied physical chemistry, and Dr. Max Le Blanc, professor of physical chemistry at Leipzig, has been elected an honorary member of the Society.

Dr. Donald D. VAN Slyke, a member of the Rockefeller Institute of Medical Research, has been awarded the Charles Mickle fellowship of the University of Toronto for his work on blood analysis, respiratory and renal reactions, diabetes and nephritis.

A Ministry of Health has recently been formed in Belgium under the direction of M. Emil Vandervelde, the well-known Socialist leader.

The twenty-fifth Congress of the German Physiological Society will be held at Giessen and Bad Nauheim on August 30-September 2 in conjunction with the German Pharmacological Society. Further information can be obtained from Prof. Dr. Burker, Physiologisches Institut, Giessen.

ThE twenty-third French Congress of Hygiene will be held at the Institut Pasteur, Paris, on October 2022, under the presidency of Prof. Leclainche. Further information can be obtained from the general secretary, Dr. R. Dujarric de la Rivière, Institut Pasteur, 28 rue du Docteur Roux, Paris, $15^{\mathrm{e}}$.

Four committees (medical, engineering, economic and legal, and administrative) have been appointed in the United States, consisting of health experts, representatives of employers, workers, insurance companies, Government, technical societies and engineers, to attempt to devise a method for putting an end to silicosis.

EIGHTY-SIX cities in the United States with an estimated population of 37 millions reported 8,799 deaths from motor accidents in 1935 as compared with 9,060 deaths in 1934. Forty-eight of the cities showed a decrease in the total number of fatalities ; thirty-six showed increases and two cities reported the same number of deaths in 1935 as in 1934 .

The fifteenth Annual Clinical and Scientific Session of the American Congress of Physical Therapy will be held at the Waldorf-Astoria Hotel, New York, on September 7-11. The programme will include symposia on short-wave diathermy, hydrotherapy, exercise, electro-resection, fever therapy, treatment of vascular diseases, the educational aspects of physical therapy, the relationship of physical technicians to physicians and hospital departments, and technical and scientific exhibits. Further information can be obtained from Dr. Norman E. Titus, 730 Fifth Avenue, New York.

Applications are invited for the following appointments, on or before the dates mentioned :

Two assistant experimental officers (Grade D) (physics or engineering) in a War Department at Woolwich-The Superintendent, Experimental Signals Establishment, Woolwich Common, S.E.18 (August 18).

A scientific officer (physics or engineering) in a Government establishment of the War DepartmentThe Secretary, Royal Engineer Board, Regent's Park Barracks, Albany Street, N.W.1 (August 26).

A chemist in the Department of War Department Chemist-The Under-Secretary of State (C.5), War Office, S.W.1 (September 7).

An assistant keeper in the Science Museum, South Kensington, S.W.7-The Director (September 7).

An Elder professor of anatomy and histology in the University of Adelaide-The Secretary, Universities Bureau of the British Empire, 88a Gower Street, W.C.1 (September 20).

A temporary lecturer in zoology in the University of Cape Town-Prof. T. A. Stephenson (October 5).

A lecturer in civil engineering and building in the Portsmouth Municipal College--The Registrar. 